J. Perinat. Med. 13 (1985) 171

\title{
Intrauterine growth retardation (IUGR) in pre-term infants
}

\author{
K. Heinonen, R. Matilainen, H. Koski, K. Launiala \\ Children's Hospital, University of Kuopio, Finland
}

\section{Introduction}

Diseases associated with prematurity are important causes of neonatal morbidity and mortality in developed countries [1,2]. Whether or not concomitant intrauterine growth retardation (IUGR) represents an additional risk factor in premature infants is a question about which there remains considerable controversy. The developmental outlook for growth-retarded prematures seems to range from high early mortality and increased incidence of neurological handicaps $[3-7]$ to a relatively favorable outcome [8]. The differences may have several causes. Some studies have evidently dealt with both pre-term and full-term infants selected on the basis of low birth weight alone. Even when the study material consisted only of pre-term infants, there may have been differences in treatment variables between study groups which would invalidate attempts to analyse the impact of retarded intrauterine growth per se on later outcome.

On the basis of examination of an entire preterm population born alive to mothers who lived in a defined geographic area during a period of two years, we have established normal values relating to somatic growth, estimated the incidence of IUGR and evaluated some factors associated with the development of IUGR. We have also analysed selected aspects of neonatal morbidity and mortality in IUGR versus normally grown premature infants.

\section{Patients and methods}

The study was performed in the province of Kuopio (population approximately 250000 ) between January 1, 1976 and December 31, 1977. Peri- and neonatal services are regionalized within the area [9]. One medical center provides care for high-risk mothers and newborn infants, including those born pre-term. The total number of infants born alive during the study period was 6,848 . Seventy per cent were born in the medical center and $30 \%$ in two local hospitals. All pre-term infants with the exception of three reached the regional medical center in utero.

A total of 209 pre-term infants (gestational age less than 37 weeks) [10] were examined during the study period. These infants represented three per cent of all live biths. According to the patient registers of the three hospitals in the study area, the group of premature infants studied represented $97 \%$ of all pre-term infants. The group may be regarded as representative of this population. For analysis of intrauterine growth, the following groups were omitted:

1) twenty-three neonates born in the regional center to residents from other areas, or referred to that center from other areas;

2) eight neonates of uncertain gestational age (a discrepancy of more than three weeks between menstrual dates and pediatric assessment of gestational age [11];

3) seven malformed infants; and 
4) fifty-one twins and triplets.

The study population consisted of 120 pre-term non-malformed singletons.

Estimates of intrauterine growth were based on weights and lengths recorded at birth. The nutritional status was assessed using ROHRER's Ponderal Index (PI) [12] [the formula: $100 \times$ birth weight $(\mathrm{g}) \times$ birth length $\left.(\mathrm{cm})^{-3}\right]$. Gestational. age was calculated on the basis of the mother's last menstrual period. One hundred and eleven of the study infants (93\%) underwent pediatric assessment of gestational age [11]. The socioeconomic status of the family was determined by the occupational-educational evaluation of the mother, classified into three main categories ( $\mathrm{I}=$ major business and professional; II = minor professional, medium business, technical, skilled craftsman; III = machine operators, salesworkers, semiskilled workers, unskilled laborers) [13]. The socioeconomic evaluation was based on the prevailing family conditions at the time of the pre-term child's birth. The distribution of socioeconomic categories among the parents of the pre-term study population was $I=1 \%$; II $=71 \%$; $\mathrm{III}=28 \%$.

Normal ranges for birth weight, birth length and PI (defined as mean \pm two standard deviations) were calculated for each gestational age group on the basis of the measurements of 51 premature neonates born to healthy mothers not experiencing complications during pregnancy (Tab. I). The distribution of socio-

Tab. I. Distribution of birth weights, lengths and PIs (means \pm one standard deviation) in a group of 51 surviving premature infants born to healthy mothers not experiencing complications during pregnancy.

\begin{tabular}{lrlll}
\hline $\begin{array}{l}\text { Gestation } \\
\text { (weeks) }\end{array}$ & $\mathrm{N}$ & $\begin{array}{l}\text { Weight } \\
(\mathrm{g})\end{array}$ & $\begin{array}{l}\text { Length } \\
(\mathrm{cm})\end{array}$ & $\mathrm{PI}$ \\
\hline$\leq 30$ & 6 & $1422 \pm 211$ & $39.4 \pm 1.3$ & $2.35 \pm 0.15$ \\
31 & 6 & $1783 \pm 202$ & $42.8 \pm 1.5$ & $2.37 \pm 0.14$ \\
32 & 6 & $2005 \pm 261$ & $43.6 \pm 1.7$ & $2.41 \pm 0.12$ \\
33 & 7 & $2239 \pm 221$ & $44.6 \pm 1.5$ & $2.50 \pm 0.16$ \\
34 & 10 & $2374 \pm 260$ & $45.3 \pm 1.6$ & $2.54 \pm 0.18$ \\
35 & 9 & $2526 \pm 262$ & $46.0 \pm 1.4$ & $2.63 \pm 0.21$ \\
36 & 7 & $2740 \pm 220$ & $46.9 \pm 1.3$ & $2.69 \pm 0.20$ \\
\hline
\end{tabular}

Tab. II. Relative birth weights, lengths and PIs in the pre-term study population $\left(\mathrm{N}=117^{*}\right)$. For numerical values of means and SDs, see Tab. I.

\begin{tabular}{|c|c|c|c|c|c|c|c|c|c|}
\hline & Weigh & & & Length & & & PIs & & \\
\hline & Gestat & (weeks) & & Gestat & (weeks) & & Gesta & (weeks) & \\
\hline & $\leq 30$ & $31-33$ & $34-36$ & $\leq 30$ & $31-33$ & $34-36$ & $\leq 30$ & $31-33$ & $34-36$ \\
\hline & & & & & & & (1) & & \\
\hline$+2 \mathrm{SD}$ & $1 * *$ & $3(1)^{* *}$ & 5 & 1(1) & 4 & 6 & 1 & $3(1)$ & 5 \\
\hline$+1 \mathrm{SD}$ & & & & & & & & & \\
\hline & 2 & 7 & 10 & $4(2)$ & $15(2)$ & $12(1)$ & 2 & 5 & 10 \\
\hline & $4(2)$ & 13 & $10(1)$ & $4(1)$ & 11 & $21(2)$ & 2 & 6 & 9 \\
\hline & $3(5)$ & 9 & $21(1)$ & 1(3) & $4(1)$ & 12 & 1(1) & $8(1)$ & $18(1)$ \\
\hline & (3) & $2(5)$ & $8(1)$ & (3) & (3) & 3 & $4(8)$ & $12(4)$ & $12(2)$ \\
\hline Total & $10(10)$ & $34(6)$ & $54(3)$ & $10(10)$ & $34(6)$ & $54(3)$ & $10(10)$ & $34(6)$ & $54(3)$ \\
\hline
\end{tabular}

* Three extremely premature infants (gestational age $\leq 24$ weeks and birth weight $\leq 590 \mathrm{~g}$ ) could not be classified as "normal" or IUGR.

** In each group, figures represent the number of infants surviving (number not in brackets) or dead (number in brackets). 
economic status among these infants $(I=0 \%$; $\mathrm{II}=72 \%$; III $=28 \%$ ) was not different from that observed in the pre-term study population. The data are similar to those reported previously [14]. Based on these normal ranges, IUGR was diagnosed in the study population if any of the growth indicators (birth weight, birth length, PI) was more than two standard deviations below the expected mean for the gestational age (Tab. II).

Statistics relating to qualitative variables were analyzed using the Chi square $\left(\chi^{2}\right)$ test with YATE's correction and the FISHER exact test when the expected number in one cell was five or less. Statistics relating to quantitative variables were analyzed using STUDENT's t-test.

\section{Results}

IUGR was common in this pre-term population (Tabs. II and III). A total of 49 neonates were so classified. A low PI was the most common descriptor of IUGR. A low PI was present in 42 of 49 IUGR infants. One-third of IUGR infants exhibited more than one indicator of retarded growth. The majority of IUGR infants (30 out of 49) had a gestational age $\leq 33$ weeks. IUGR was suspected antenatally in 18 infants $(37 \%)$.

Tab. III. The anthropometric indicators of retarded growth in 49 per-term IUGR infants.

\begin{tabular}{lccc}
\hline Indicator(s) of IUGR & $\begin{array}{l}\text { Number } \\
\text { of } \\
\text { infants }\end{array}$ & $\begin{array}{l}\text { Number of } \\
\text { case } \\
\text { fatalities* }\end{array}$ \\
\hline Birth weight & $<-2$ SD & 5 & 1 \\
PI & $<-2$ SD & 30 & 7
\end{tabular}

\begin{tabular}{|c|c|c|c|}
\hline $\left.\begin{array}{l}\text { Birth weight } \\
\text { Birth length }\end{array}\right\}$ & $<-2 \mathrm{SD}$ & 2 & 1 \\
\hline $\left.\begin{array}{l}\text { Birth weight } \\
\text { PI }\end{array}\right\}$ & $<-2 \mathrm{SD}$ & 5 & 2 \\
\hline $\left.\begin{array}{l}\text { Birth weight } \\
\text { Birth length } \\
\text { PI }\end{array}\right\}$ & $<-2 \mathrm{SD}$ & 7 & 5 \\
\hline Total & & 49 & 16 \\
\hline
\end{tabular}

* includes both neonatal and postneonatal deaths
In the IUGR group, there were more (nine out of 21) young primigravidas (age $\leq 19$ years) than in the group of mothers of normally grown, pre-term infants (four out of 38$)\left(\chi^{2}=\right.$ $8.23, \mathrm{p}<0.01)$. In other respects, the distributions of maternal age and parity were similar in these groups. The mean values for maternal height were also similar in both groups. The number of heavy smokers $(>20$ cigarrettes per day) in this population was eight. Two of these gave birth to IUGR infants.

A strong association between maternal disease or complications of pregnancy and the development of IUGR was evident (Tab. IV). Abnormal maternal histories were found significantly more often in relation to pre-term, IUGR group infants (45 out of 49 cases) than in appropriately grown, pre-term infants (31 out of 68) $\left(\chi^{2}=26.76, p<0.001\right)$. Quantitatively, the most important maternal conditions associated with IUGR in pre-term infants were essential hypertension, toxemia of pregnancy (hypertensive disease of pregnancy with proteinuria) [15] and prolonged leakage of amniotic fluid (for $\geq 72$ hours prior to the delivery).

Tab. IV. Maternal histories in relation to the pre-term study population $\left(\mathrm{N}=117^{*}\right)$.

\begin{tabular}{|c|c|c|}
\hline & $\begin{array}{l}\text { IUGR } \\
\mathrm{N}=49\end{array}$ & $\begin{array}{l}\text { Normal } \\
N=68\end{array}$ \\
\hline Uncomplicated pregnancy & $2 * *(2) * *$ & $34(3)$ \\
\hline Complicated pregnancy & 31 (14) & 31\#\#\# \\
\hline Toxemia and hypertension & 13 (7) & 5\#\#\# \\
\hline Prolonged leakage of amniotic & & \\
\hline fluid for $24-71$ hours & 1 & 13 \\
\hline for $\geq 72$ hours $* * *$ & $5 \quad(6)$ & 7\#\# \\
\hline Other**** & 12 (1) & 6 \\
\hline
\end{tabular}

* and ** See Tab. II for details

*** Range 3 to 23 days $(5.5 \pm 4.4$, mean \pm 1 SD)

$* * * * \quad$ For example: diabetes and hypertension, psychiatric disorders, congenital heart disease, prolonged urinary tract infection, anomaly of the uterus

$\begin{array}{ll}\# \# & \mathrm{p}<0.01 \\ \# \# \# & \mathrm{P}<0.001\end{array}$

The majority of study infants (79 out of 117 , $68 \%$ ) were born vaginally in the vertex presen- 
tation without use of forceps. Nineteen of the infants were IUGR and 60 were normally grown for their gestational age. In comparison with normally grown neonates, low $(\leq 6)$ oneminute APGAR scores were markedly more frequent among IUGR infants (14 out of 19 vs. five out of 60$)\left(\chi^{2}=33.74, p<0.001\right)$, and there were more cases of severe acidosis $(\mathrm{pH} \leq 7,20)$ during the first day of life (10 out of 14 vs. two out of 16$)\left(\chi^{2}=10.68, p<0.01\right)$. In 10 cases, breech delivery by vagina was accomplished. All the infants concerned were severely depressed at birth. Thirty-one of the study infants $(26 \%)$ were born by caesarean section. Most (21) caesarean sections were undertaken because of maternal hypertension or toxemia of pregnancy. The remaining 10 were performed because of abnormal position of the fetus, significant antepartum hemorrhage or prolapse of the cord. The majority of infants in this group (26 out of 31) were IUGR. Low ( $\leq 6)$ one-minute APGAR scores were more frequently found among IUGR infants born vaginally than among IUGR infants born by caesarean section (18 out of 23 vs. 13 out of 26 ) $\left(\chi^{2}=4.19, \mathrm{p}<0.05\right)$.

Resuscitation (positive pressure ventilation using oxygen) at birth was required by 30 out of 49 IUGR-infants. Fifteen of these infants died during the neonatal period. In contrast, significantly fewer (22 out of 68$)\left(\chi^{2}=9.61\right.$, $\mathrm{p}<0.01)$ normally grown infants required resuscitation at birth, and all survived the neonatal period.

IUGR in pre-term infants was not associated with favorable neonatal course (Tab. V). The occurrence of several neonatal disorders (respiratory distress, hyperbilirubinaemia and hypoglycemia) was similar in both IUGR and normally grown premature infants. Some problems (apneic attacks and feeding difficulties) were more common in IUGR infants than in normally grown premature infants. Sixteen neonates $(13 \%)$ required only supportive nursing care during their stay in hospital. Fifteen were normally grown for their gestational age whereas only one belonged to IUGR group $\left(\chi^{2}=9.67, \mathrm{p}<0.01\right)$.
Tab. V. Neonatal course of the pre-term study population $\left(\mathrm{N}=117^{*}\right)$.

$\begin{array}{ll}\text { IUGR } & \text { Normal } \\ \mathrm{N}=49 & \mathrm{~N}=68\end{array}$

Infants with uneventful neona-

tal course

Infants experiencing various

disorders***

Respiratory distress

Apnea, convulsions

Hyperbilirubinemia

Hypoglycemia

Septic infections

Prolonged feeding difficulties

$\begin{array}{rl}1 & 15 \\ 48 & 53 \\ 22 & 35 \\ 12 & 3 \# \# \# \\ 6 & 3 \\ 6 & 4 \\ 3 & 5 \\ 20 & 8 \# \# \#\end{array}$

* See Tab. II for details

*** More than one disorder may have been present in the same infant

\#\#\# $\mathrm{P}<0.001$

As a group, pre-term IUGR infants had significantly higher total mortality (15 neonatal and one postneonatal deaths, $32 \%$ ) than normally grown pre-term infants (three neonatal deaths, $4 \%$ ). In addition, three neonatal deaths were thought to be unavoidable because of extreme prematurity (gestational age $\leq 24$ weeks, birth weight $\geq 590 \mathrm{~g}$ ). Infants with more than one indicator of IUGR had higher neo- and postneonatal mortality than infants with only one descriptor of IUGR (eight out of $14 \mathrm{vs.}$ eight out of 35$)\left(\chi^{2}=5.35, p<0.025\right)$. After vaginal delivery in the vertex presentation, the mortality of pre-term IUGR infants (eight out of 19) was significantly higher than that among normally grown prematures (three out of 60) $\left(\chi^{2}=16.58, p<0.001\right)$.

An autopsy was performed upon all infants who died. Fatal cerebral bleeding was found in five out 20 infants $(25 \%)$ at $\leq 30$ weeks, in two out of 40 infants (five \%) between 31 and 33 weeks and in one of 57 infants (two \%) between 34 and 36 weeks. Six out of eight bleedings were severe forms of intraventricular hemorrhage (IVH). One subarachnoidal hemorrhage and one intracerebral-posterior fossa hemorrhage were also found. All infants with fatal cerebral bleeding belonged to the IUGR group. Six of them were born vaginally in either the vertex or the breech presentation. 


\section{Discussion}

There is general agreement that IUGR represents a continuum of various degrees of reduction of gain in weight as well as of associated reduction in linear growth, depending on the time of onset, duration and severity of causative insult $[1-8,16-18]$. The common definition of IUGR as "low birth weight in relation to gestational age" [16] therefore relates to only one form of several IUGR variants [17-18]. This is evident in the present study, in which diagnosis of IUGR was based not only upon low birth weight but also on other anthropometric indicators of growth restriction, and in which the lower limits of normal range were defined as values equal to two standard deviations less than the expected mean for the gestational age. On this basis, low birth weight identified only $39 \%$ of infants with IUGR. A low PI was found in $86 \%$ of IUGR infants. Low PI, therefore, seems to be a better indicator of IUGR in pre-term infants than a low birth weight. Reduction of linear growth was present in only $18 \%$ of IUGR infants.

Etiologically, infants with IUGR represent a very heterogeneous group $[15,16-18]$. The present investigation focused on a population of pre-term singletons, born to women with similar standards of living and nutrition, receiving similar medical care throughout delivery and afterwards. Under these circumstances, differences in socioeconomic factors, which are known to exert powerful influence upon fetal growth [16] were eliminated. Determinants of IUGR such as malformations, the incidence and birthweight distribution of which are probably governed by factors outwith the perinatal health services, were also excluded. Nevertheless, the number of pre-term IUGR-infants in this study was high. Development of IUGR was strongly associated with perinatal maternal pathology. Maternal disease and complications of pregnancy (essential hypertension, toxemia and prolonged leakage of amniotic fluid) were the commonest perinatal factors associated with the development of pre-term IUGR. An adverse maternal history was present in $94 \%$ all pre-term IUGR cases, and often led to fetal growth retardation at relatively early stages of gestation ( $\leq 33$ weeks).

The present data show that in a population of pre-term non-malformed infants, IUGR is associated with poor neonatal outcome. IUGR infants exhibited a higher neonatal mortality, and more apneic attacks, convulsions and feeding difficulties as well as a greater necessity for resuscitation at birth than appropriately-grown pre-term infants of corresponding gestational age. In contrast to these observations, markedly better survival rates for pre-term IUGR infants have been reported [8]. Such studies are based on retrospective analysis of selected (transported) patient groups with non-matched perinatal treatment variables. The results therefore may not be applicable to pre-term infants on a population basis.

Pre-term IUGR infants are obviously at particular risk for perinatal hypoxia. Previous followup studies [3-4] have shown that surviving IUGR infants often have neurological defects indicating ischemia in periventricular regions. In our study, fatal IVH was found only in the IUGR group. These observations suggest that careful screening of pre-term IUGR groups for IVH (by ultrasound or computerized tomography) as well as follow-up of pre-term IUGR survivors for detection of sequelae of hypoxic ischemic brain insults would be of value.

With the present stage of knowledge, it is uncertain whether health service intervention at any level would be effective in reducing morbidity and mortality associated with pre-term IUGR. Attempts at management must obviously start with timely recognition. In the present study, antenatal diagnosis was achieved in approx. $37 \%$ of all IUGR cases, whereas previous reports indicate a much less consistent detection of pre-term IUGR [4]. Clearly, greater effort should be directed towards the antenatal identification of pre-term IUGR, especially in cases of maternal disease or complications of pregnancy. Once IUGR is suspected, antenatal fetal monitoring and early delivery (preferably by caesarean section, if signs of fetal distress appear) are usually advocated $[4,19]$. So far, the 
beneficial effects of such intervention have been demonstrated only in retrospective studies [19]. Data from the few controlled clinical trials are conflicting [20]. Prospective epidemiological studies are needed in which there is adequate matching of study groüps for perinatal variables and intrauterine growth, if associations between various treatment modalities and subsequent health status are to be evaluated in preterm infants.

\section{Summary}

A representative sample $(\mathrm{N}=120,96 \%)$ of all preterm (gestational age $\leq 36$ weeks) infants born alive to mothers resident in the province of Kuopio, Finland, during a two year period, were studied at birth to evaluate the signs of intrauterine growth retardation (IUGR). Norms for somatic growth were based on measurements of birth weight, length and Ponderal Index $(100 \times$ birth weight $(\mathrm{g}) \times$ birth length $\left.(\mathrm{cm})^{-3}\right)$ of 51 pre-term singletons, born to healthy mothers after uncomplicated pregnancies, in relation to whom there were no discrepancies between menstrual dates and pediatric assessment of gestational age. The lower limits for normal ranges were defined as values two standard deviations below the expected means for the gestational age.

Pre-term IUGR was diagnosed if birth weight and/or birth length and/or PI were more than 2 SD below the expected mean for gestational age. Different types of IUGR were found in 49 pre-term infants $(41 \%$ of the pre-term population). A low PI was the most common descriptor of IUGR, being present in 42 out of 49 infants. A third of infants had more than one indicator of IUGR. In this population, pre-term IUGR was strongly associated with perinatal maternal pathology (especially hypertension, toxemia and prolonged leakage of amniotic fluid).

The neonatal morbidity and mortality among pre-term IUGR infants was markedly higher than that among appropriately grown pre-term infants with corresponding gestational age. There were significantly more cases with fatal intraventricular hemorrhage in pre-term IUGR than in pre-term normally-grown infants. These findings suggest that close follow-up of pre-term IUGR infants would be of value for the detection of later sequelae of hypoxic ischemic encephalopathy.

IUGR obviously limits the capacity of perinatal adaptation in pre-term infants. If the effects of various perinatal treatment variables on the subsequent health status of pre-term infants are to be evaluated, allowance should be made for adequate matching for intrauterine growth status among the infants concerned.

Keywords: Intrauterine growth retardation, neonatal morbidity, neonatal mortality, pregnancy complications, prematurity.

\section{Zusammenfassung}

Intrauterine Mangelentwicklung bei Frühgeborenen Eine repräsentative Auswahl $(\mathrm{N}=120,96 \%)$, getroffen unter allen im Laufe zweier Jahre vorzeitig (Gestationsalter $\leq 36$ Wochen) lebendgeborenen Kindern im Bezirk Kuopio/Finnland, wurde nach der Geburt auf eventuelle Anzeichen einer intrauterinen Wachstumsverzögerung (IUGR) untersucht. Die Normen zur physischen Entwicklung gründeten auf der Erfassung von Geburtsgewicht und Geburtslänge sowie einem Gewichtsindex $(100 \times$ Geburtsgewicht $(\mathrm{g}) \times$ Geburtslänge $(\mathrm{cm})^{-3}$ ) bei 51 frühzeitig geborenen Einlingen von gesunden Müttern, bei denen die Entbindung nach einer komplikationslosen Schwangerschaft erfolgte und keine Diskrepanzen zwischen Menstruationsdaten und kinderärztlicher Schätzung des Gestationsalters vorlagen. Als untere Grenze des Normalbereiches wurde jeweils der Wert gewählt, der zwei Standardabweichungen (SD) unter dem erwarteten Durchschnitt des Gestationsalters lag.

Eine präterminale IUGR wurde diagnostiziert, wenn das Geburtsgewicht und/oder die Geburtslänge und/oder der Gewichtsindex um mehr als zwei SD unter dem erwarteten Durchschnitt des Gestationsalters lagen. Verschiedene IUGR-Merkmale wurden bei 49 Frühgeborenen ( $41 \%$ der Frühgeburtengruppe) erkannt. Hiervon war das häufigste ein niedriger Gewichtsindex, der bei 42 von 49 Säuglingen festgestellt wurde. Ein Drittel aller Säuglinge wies mehr als ein IUGR-Merkmal auf. In dieser Gruppe ließ sich eine starke Korrelation zwischen der Präterminal-IUGR des Frühgeborenen und einer perinatalen mütterlichen Pathologie (vor allem Hochdruck, Gestose und vorzeitigem Blasensprung) beobachten.

Neonatale Morbidität und Mortalität waren bei IUGRFrühgeborenen bedeutend höher als bei normal entwikkelten Frühgeborenen entsprechenden Gestationalters. Tödliche intraventrikuläre Blutungen waren bei IUGRFrühgeborenen signifikant häufiger als bei normal entwickelten Frühgeborenen. Diese Befunde sprechen dafür, daß eine intensive Überwachung der IUGR-Frühgeborenen zur Erkennung von Spätfolgen einer hypoxischischämischen Enzephalopathie wertvoll sind. 
Die IUGR scheint die perinatale Adaptation Frühgeborener drastisch einzuschränken. Bei der Auswertung der Folgen verschiedener perinataler Behandlungsformen auf den künftigen Gesundheitszustand der Neugeborenen ist für die Auswahl der Untersuchungsgruppen das intrauterine Wachstum dieser Kinder zu berücksichtigen.

Schlüsselwörter: Frühgeburtlichkeit, intrauterine Mangelentwicklung, Neugeborenen-Morbidität, -Mortalität, Risikoschwangerschaft.

\section{Résumé}

Retard de croissance intra-utérine (R. C. I. U.) chez les enfants prématurés

Un échantillon représentatif $(r=120,96 \%)$ de tous les enfants prématurés (âge gestationnel 36 semaines) nés vivants de mères résidant dans la province de Kuopio, Finlande, a été étudié, sur une période de deux ans, au moment de la naissance pour évaluer des signes de retard de croissance intra-utérine (R. C. I. U.). Les normes de croissance somatique ont été étudiées sur la base des poids, des tailles et de l'index pondéral (PI, Pondéral Index $)(100$ poids de naissance $(\mathrm{g}) \times$ taille de naissance $\left.(\mathrm{cm})^{-3}\right)$ de 51 prématurés nés de mères en bonne santé après une grossesse simple sans complication chez lesquelles aucune discordance entre les dates des règles et l'estimation de l'âge gestationnel par le pédiatre n'a été relevée. La limite inférieure de la frange normale a été définie avec comme valeur deux déviations standards audessous de la moyenne attendue pour l'âge gestationnel. Le R. C. I. U. avant terme a été diagnostiqué si le poids de naissance et/ou le PI étaient situés plus de deux déviations standards au-dessous de la moyenne attendue pour l'âge gestationnel. 49 enfants prématurés ont présenté différents types de R.C.I. U. (41 p. 100 de la population des prématurés). L'élément descriptif le plus fréquent du R. C. I. U. était un PI bas, présent chez 42 des 49 enfants. Un tiers de tous les enfants a présenté plusieurs éléments descriptifs du R. C. I. U. Dans cette population le R.C.I. U. avant terme a été fortement associé à la pathologie périnatale maternelle (en particulier hypertension, toxémie et perte de liquide amniotique).

La morbidité et la mortalité néonatales chez les enfants prématurés avec R. C. I. U. ont été manifestement plus fréquentes que chez les enfants prématurés d'âges gestationnels correspondants avec une croissance normale. Les enfants prématurés avec $R$. C. I. U. ont présenté d'une façon significative plus de cas d'hémorragie interventriculaire fatale que les enfants prématurés de croissance normale. Ces résultats semblent indiquer qu'il serait très approprié de suivre attentivement la croissance des prématurés avec R. C. I. U. pour pourvoir détecter les séquelles tardives de l'encéphalopathie avec hypoxie et ischémie.

Il est évident que le R. C. I. U. freine radicalement la capacité d'adaptation périnatale chez les prématurés. $\mathrm{Si}$ l'on veut évaluer les effets des diverses variables de traitement périnatal sur l'état de santé subséquente, il faudrait s'assurer que les enfants concernés sont bien au même niveau de croissance intra-utérine.

Mots-clés: Complications de grossesse, morbidité néonatale, morbalité néonatale, prématurité, retard de croissance intra-utérine.

\section{Bibliography}

[1] Kutchen, W. H., V. Y. H. Yu, J. V. LisSENDEN, B. BAJUK: Collaborative study of very low birthweight infants: Techniques of perinatal care and mortality. Lancet i (1982) 1454

[2] Kitchen, W. H., V. Y. H. Yu, A. Orgill, et al.: Collaborative study of very low birthweight infants: Outcome of two-year-old survivors. Lancet i (1982) 1457

[3] Fitzhardinge, P. M., K. E. PaPe: Intrauterine growth retardation (IUGR): An added risk to the pre-term infant. Pediatr. Res. 11 (1977) 562

[4] Commey, J. O. O., P. M. Fitzhardinge: Handicap in preterm small for gestational age infant. J. Pediatr. 94 (1979) 779
[5] Kumar, S. P., E. K. Anday, L. M. Sacks, R. Y. TING, M. Delivoria-Papadopoulus: Follow-up studies of very low birth weight infants (1.250 grams or less) born and treated within a perinatal center. Pediatrics 66 (1978) 438

[6] ARIAS, F., P. TOMICH: Etiology and outcome of low birth weight and preterm infants. Obstet. Gynecol. 60 (1982) 277

[7] STARfield, B., M. McCormick: Mortality and morbidity in infants with intrauterine growth retardation. J. Pediatr. 101 (1982) 978

[8] Vohr, B. R., W. OH, A. G. Rosenfield, R. M. COWETT: The preterm small for gestational age infant: A two-year follow-up study. Am. J. Obstet. Gynecol. 133 (1979) 425 
[9] Perinatal Status 1975. Perinatal Committee Report, Finnish Medical Association, Helsinki 1978

[10] WHO: Public health aspects of LBW. Technical Report Series No. 217, Geneva 1961

[11] Dubowitz, L. M. S., V. Dubowitz, C. GoldberG: Clinical assessment of gestational age in the newborn infant. J. Pediatr. 77 (1970) 1

[12] RoHrer, F.: Der Index der Körperfülle als Mass des Ernährungszustandes. MMW 68 (1921) 580

[13] Rauhala, U.: . Suomalaisen yhteiskunnan sosiaalinen kerrostuneisuus. (The social stratification of the Finnish society). Helsinki: WSOY 1966

[14] ULRICH, M.: Fetal growth pattern in a population of Danish newborn infants. Acta Paediatr. Scand. (Suppl.) 292 (1982) 10

[15] MacGillivray, I., D. M. Campbell, L. Jandial: The effect of pregnancy hypertension on fetal growth. In: VAN ASSCHE, F. A., W. B. RoBERTSON: Fetal growth retardation. Churchill Livingstone, Edinburgh 1981
[16] Lubchenco, L.: Thè high risk infant. W. B. Saunders Company, Philadelphia, London, Toronto 1976, p. 99

[17] Miller, H. C., K. HassanenN: Diagnosis of impaired fetal growth in newborn infants. Pediatrics 48 (1971) 511

[18] MilleR, H. C.: Fetal growth and neonatal mortality. Pediatrics 49 (1972) 392

[19] LinZey, E. M., R. K. FreEman: Antepartum fetal monitoring. In: Year book of obstetrics and gynecology. Year Book Medical Publishers, Chicago 1978, p. 85

[20] Banta, D. H., S. ThaCKer: Policies toward medical technology: The case of electronic fetal monitoring. Am. J. Public Health 69 (1979) 931

Received February 20, 1984. Revised May 24, 1984. Accepted July 18, 1984.

Kirsti Heinonen, M. D., Children's Hospital University of Kuopio 70210 Kuopio 21, Finland 